\title{
IMPACT OF CANAL WATER QUALITY TO THE MORPHOLOGY AND PHYSIOLOGY OF CULTIVATED PLANTS
}

\author{
Antonije Žunić3 346 \\ Slavica Vukovićc ${ }^{347}$ \\ Sanja Lazićc ${ }^{348}$ \\ Dragana Šunjka ${ }^{349}$ \\ Jelena Tričkovićc 350
}

https://doi.org/10.31410/itema.2018.1025

\begin{abstract}
Agriculture represents one of the main sources of water pollution, but it is also a significant user of canal water resources through irrigation. In order to prevent and reduce environmental pollution, it is essential to conduct the continuous monitoring of water quality using cultivated plants as phytoindicators. The assessment of possibly use of canal water for irrigation and determination of appropriate phytoindicator was conducted in bioassay using lettuce (Lactuca sativa L.) and radish (Raphanus sativus L.) as test plants. The analyzed (physico-chemical parameters) samples of canal waters was taken from two localities in Vojvodina Province, Serbia (Kovilj and Sirig). Physiological and morphological parameters of the test plants were used for evaluation of water quality by method ISTA (2013) and according to the Regulations on the seed quality for agricultural plants in Serbia. Results for physiological parameters are expressed in percentages. The values of morphological parameters are expressed as average values and are processed using the ANOVA and LSD test, with confidence interval of $95 \%$. The obtained results indicate differences in tolerance of the test plants towards the quality of water. Physiological parameters (germination energy and germination) are not appropriate indicators of water quality. Morphological traits such as length of root can be considered more reliable, which reacted in inhibition, depending on water quality.
\end{abstract}

Keywords: water, pollutants, monitoring, phytoindicators, lettuce, radish

\section{INTRODUCTION}

$\mathrm{W}$ ater plays a significant role in the economic progress of any country and specifically the countries that depend on the agricultural production, which also represents one of the main sources of water pollution. Pesticidal residues carried by water from agricultural areas pose an environmental threat as a result of intensive agricultural production and irrigation. In order to prevent and reduce environmental pollution, it is essential to conduct the continuous monitoring of water quality using cultivated plants as phytoindicators. Organisms that are used to detect changes in the environment and demonstrate the presence of pollutants and their effects on the ecosystem in which the organism lives, are called bioindicators. The changes can be chemical, physical or behavioral changes, and are different from organism to organism. Every organism in the ecosystem can provide information about

\footnotetext{
${ }^{346}$ University of Novi Sad, Faculty of Agriculture, Novi Sad, Serbia

${ }^{347}$ University of Novi Sad, Faculty of Agriculture, Novi Sad, Serbia

${ }^{348}$ University of Novi Sad, Faculty of Agriculture, Novi Sad, Serbia

${ }^{349}$ University of Novi Sad, Faculty of Agriculture, Novi Sad, Serbia

${ }^{350}$ University of Novi Sad, Faculty of Sciences, Novi Sad, Serbia
} 
the health of their environment. The most used test organisms in bioassays for quality assessment and water pollution are aquatic invertebrates (lower plants) and also macrophytes (higher plants), especially cultivated plant species, in case of assessing the quality of water in the agricultural region. The aim of the study was to determine the degree of water pollution through physiological (germination energy, germination) and morphological parameters (length of roots and shoots, fresh and dry weight of roots and shoots) by using test plants radish (Raphanus sativus L.) and lettuce (Lactuca sativa L.). The results of bio-assays directly indicate water suitability for irrigation and cultivation of plants.

\section{MATERIAL AND METHODS}

Water sampling was conducted in 2018 on the territory of Vojvodina from two sites: Kovilj and Sirig. Chemical analyzes of water samples were carried out by an expert team from Department of Chemistry, Biochemistry and Environmental Protection, Faculty of Sciences Novi Sad (Novi Sad, Serbia). Chemical analysis included examination of general parameters: electroconductivity, $\mathrm{pH}$, total nitrogen, total phosphorus, ammonia, nitrates and nitrites. In the interpretation of results are used the maximum allowable values of prescribed regulations (Official Gazette of RS, no. 50/2012, 35/2011, 50/2012). As test plants a representative of two dicots - radish (R. sativus) and lettuce (L. sativa) were chosen. The quality of water is evaluated using physiological (germination energy and germination $/ \% /$ ) and morphological parameters (length of roots and shoots / cm /, fresh and dry weight of roots and shoots / g /) of test plants. A filter-paper method by ISTA (International rules for seed testing) for 2013 and the Regulations of the seeds quality for agricultural plants (,Sl. List SFRJ“, no. 47/87, 60/87, 55/88 and 81/89 and „Sl. List SRJ“, no. 16/92, 8/93, 21/93, 30/94, 43/96, 10/98, 15/2001 and 58/2002) was used. The Petri dishes were filled with two layers of cotton wool paper at the bottom, over which is placed filter paper. Paper was soaked with $25 \mathrm{ml}$ of sampled water or with distilled water as control variant. Then, after each repetition 100 seeds were placed in Petri dishes (in the same manner and with the same quantity of sample water). Then the Petri dishes were stored in a thermostat at a temperature of $25 \pm 2^{\circ} \mathrm{C}$, in the dark. The experiment was set in four replications. Seed germination was determined after 10 days. Germination energy and germination were assessed by counting the germinated seeds, un-germinated and atypical seedlings compared to the total number and expressed in percentages. In order to assess the morphological parameters, from each repetition 10 plants were selected and placed on the threelayer paper strips dimensions $14 \times 60 \mathrm{~cm}$ in size. The strips were pre-moistened with $30 \mathrm{ml}$ of test water, then wrapped in rolls, placed in plastic bags and then stored in a thermostat. After 10 days, the length of root and shoot from the rolls were measured. Fresh root and shoot weight was measured on an analytical, digital balance. When the measurement of fresh weight is done, metal containers with samples were placed in the oven at $60^{\circ} \mathrm{C}$ for $24 \mathrm{~h}$ and 1 hour at $130^{\circ} \mathrm{C}$, and finally dry weight of root and shoot was measured. Results for germination energy and germination are expressed in percentages. The values of morphological parameters are shown as average values and are processed using the Analysis of Variance and Duncan's multiple comparison test, with confidence interval of $95 \%$, in the statistical software $\mathrm{R}$ ver. 3.2.2.

\section{RESULTS AND DISCUSSION}

\subsection{Physico-chemical analysis of water}

According to the results of physico-chemical analysis, in water sample Sirig and Kovilj electrical conductivity did not exceeded maximum allowed values. Electrical conductivity, concentration of salt in the water, is an essential characteristic of water for irrigation and it 
significantly affects the crops productivity. The primary effect of high salt concentration is reflected in plant the inability to uptake water from the soil solution which leads to a physiological drought. The higher the conductivity, the less water is available to plants (Bauder et al., 2014). Also, pH results were below the maximum allowable values. However, in water samples Sirig and Kovilj a high concentration of ammonia was established (exceeding maximum allowable concentration for $3 \mathrm{x}$ ), while the other test parameters were in allowable limits.

Table 1. Physico-chemical analysis of the general parameters in analyzed water samples

\begin{tabular}{|c|c|c|c|c|c|c|c|c|}
\hline \multirow[b]{2}{*}{ Location } & \multicolumn{8}{|c|}{ Detected values of general parameters } \\
\hline & $\mathbf{p H}$ & $\begin{array}{c}\mathrm{EC}(\mathrm{mS} / \mathrm{cm}) \\
\text { at } 20^{\circ} \mathrm{C}\end{array}$ & $\begin{array}{l}\mathrm{NO}_{3}^{-} \\
\mathrm{mgN} / \mathrm{l}\end{array}$ & $\begin{array}{l}\mathrm{NO}_{2}^{-} \\
\mathrm{mgN} / \mathrm{l}\end{array}$ & $\begin{array}{c}\mathrm{NH}_{3} \\
\mathrm{mgN} / \mathrm{l}\end{array}$ & $\underset{\mathrm{mgCl} / \mathrm{l}}{\mathrm{Cl}}$ & $\begin{array}{c}\mathrm{Fe} \\
\mathrm{mgFe} / \mathrm{l}\end{array}$ & $\begin{array}{c}\mathrm{Ca} \\
\mathrm{mgCa} / \mathrm{l}\end{array}$ \\
\hline Sirig & 7.8 & 1189 & 1.1 & $<0.005$ & 0.29 & 95.5 & $<0.1$ & 46.9 \\
\hline Kovilj & 7.9 & 1232 & 2.2 & $<0.005$ & 0.37 & 67.7 & $<0.1$ & 84.7 \\
\hline *MAC & $6-9$ & 2500 & 50.0 & 0.03 & 0.1 & 200 & 0.3 & 200 \\
\hline
\end{tabular}

\subsection{Bioassay results - radish and lettuce}

The obtained results indicate differences in tolerance of the test plants according to the parameters which have been detected in the water. Although the differences between control and water samples were significant, values for germination and germination energy were above the prescribed limits for those plant species.

Table 2. Water quality influence on physiological parameters

\begin{tabular}{|c|c|c|c|}
\hline Parameters & Water sample & Radish & Lettuce \\
\hline \multirow{4}{*}{$\begin{array}{l}\text { Germination } \\
\text { energy }(\%)\end{array}$} & Sirig & $94.0 \pm 1.15 \mathrm{a}$ & $92.75 \pm 2.63 \mathrm{~b}$ \\
\hline & Kovilj & $95.5 \pm 1.29 b$ & $93.75 \pm 2.06 \mathrm{ab}$ \\
\hline & Control & $97.5 \pm 1.29 \quad b$ & $96.50 \pm 0.57 \mathrm{a}$ \\
\hline & F value & 7.93* & $3.93 *$ \\
\hline \multirow{4}{*}{$\begin{array}{c}\text { Germination } \\
(\%)\end{array}$} & Sirig & $96.5 \pm 1.29 \mathrm{~b}$ & $96.0 \pm 1.41 \mathrm{ab}$ \\
\hline & Kovilj & $95.7 \pm 0.96 \mathrm{~b}$ & $94.5 \pm 0.30 \quad b$ \\
\hline & Control & $98.5 \pm 0.58 \mathrm{a}$ & $98.0 \pm 0.81 \mathrm{a}$ \\
\hline & F value & $8.31 *$ & $3.00 *$ \\
\hline
\end{tabular}

Based on this results it can be concluded that physiological parameters (germination energy and germination), in both cases, have not been proven to be good indicators of water quality, while some morphological parameters of radish and lettuce (length of root), that reacted by inhibition, may be considered more reliable. Other morphological parameters were not affected by water quality and all values are on the same level of significance, compared to the control. Root length of radish was significantly inhibited by water from Sirig (20.2\%) and Kovilj (45.1\%), compared to the control. Also, root length of lettuce was significantly inhibited by water from Sirig and Kovilj by 53.7 and $59.7 \%$ respectively. Radish and lettuce proved that they could be used as good indicator of water quality, which is contaminated with specified pollutants. 
Table 3. Impact of water quality on morphological parameter

\begin{tabular}{|c|c|c|c|}
\hline \multirow{2}{*}{ Parameters } & \multirow{2}{*}{ Water sample } & Radish & Lettuce \\
\hline & & Values & Values \\
\hline \multirow{4}{*}{$\begin{array}{l}\text { Length of } \\
\operatorname{root}(\mathrm{cm})\end{array}$} & Sirig & $4.51 \pm 0.77 \mathrm{a}$ & $0.93 \pm 0.19 \quad b$ \\
\hline & Kovilj & $3.10 \pm 1.29 \mathrm{~b}$ & $0.81 \pm 0.15 \quad b$ \\
\hline & Control & $5.65 \pm 0.23 \mathrm{a}$ & $2.01 \pm 0.36 \mathrm{a}$ \\
\hline & F value & $8.43 *$ & $27.61 *$ \\
\hline \multirow{4}{*}{$\begin{array}{c}\text { Fresh weight } \\
\text { of root (g) }\end{array}$} & Sirig & $0.17 \pm 0.07 \mathrm{a}$ & $0.01 \pm 0.01 \quad \mathrm{a}$ \\
\hline & Kovilj & $0.06 \pm 0.01 \mathrm{a}$ & $0.01 \pm 0.01 \quad \mathrm{a}$ \\
\hline & Control & $0.07 \pm 0.03 \mathrm{a}$ & $0.02 \pm 0.01 \quad \mathrm{a}$ \\
\hline & F value & $2.80 \mathrm{~ns}$ & $2.46 \mathrm{~ns}$ \\
\hline \multirow{4}{*}{$\begin{array}{l}\text { Dry weight } \\
\text { of root (g) }\end{array}$} & Sirig & $0.02 \pm 0.010 \mathrm{a}$ & $0.002 \pm 0.001 \mathrm{a}$ \\
\hline & Kovilj & $0.01 \pm 0.007 \mathrm{a}$ & $0.001 \pm 0.001 \mathrm{a}$ \\
\hline & Control & $0.01 \pm 0.003 \mathrm{a}$ & $0.001 \pm 0.001 \mathrm{a}$ \\
\hline & F value & $2.80 \mathrm{~ns}$ & $2.03 \mathrm{~ns}$ \\
\hline \multirow{4}{*}{$\begin{array}{l}\text { Length of } \\
\text { shoot }(\mathrm{cm})\end{array}$} & Sirig & $2.37 \pm 0.56 \mathrm{a}$ & $4.16 \pm 0.87 \mathrm{a}$ \\
\hline & Kovilj & $2.48 \pm 1.01 \mathrm{a}$ & $3.69 \pm 0.92 \mathrm{a}$ \\
\hline & Control & $1.96 \pm 0.54 \mathrm{a}$ & $3.64 \pm 0.78 \mathrm{a}$ \\
\hline & F value & $0.56 \mathrm{~ns}$ & $0.43 \mathrm{~ns}$ \\
\hline \multirow{4}{*}{$\begin{array}{c}\text { Fresh weight } \\
\text { of shoot (g) }\end{array}$} & Sirig & $0.23 \pm 0.23 \mathrm{a}$ & $0.25 \pm 0.06 \mathrm{a}$ \\
\hline & Kovilj & $0.08 \pm 0.99 \mathrm{a}$ & $0.24 \pm 0.05 \quad \mathrm{a}$ \\
\hline & Control & $0.17 \pm 0.13 \mathrm{a}$ & $0.20 \pm 0.42 \quad \mathrm{a}$ \\
\hline & F value & $0.83 \mathrm{~ns}$ & 0.99 ns \\
\hline \multirow{4}{*}{$\begin{array}{l}\text { Dry weight } \\
\text { of shoot (g) }\end{array}$} & Sirig & $0.015 \pm 0.099 \mathrm{a}$ & $0.007 \pm 0.002 \mathrm{a}$ \\
\hline & Kovilj & $0.013 \pm 0.008 \mathrm{a}$ & $0.008 \pm 0.002 \mathrm{a}$ \\
\hline & Control & $0.009 \pm 0.005 \mathrm{a}$ & $0.007 \pm 0.001 \mathrm{a}$ \\
\hline & F value & $0.35 \mathrm{~ns}$ & $0.21 \mathrm{~ns}$ \\
\hline
\end{tabular}

\section{CONCLUSION}

Based on the conducted tests and the results achieved on the influence of water quality (Sirig, Kovilj) on the test plants (radish, lettuce) it can be concluded that:

- In water samples Sirig and Kovilj a high concentration of ammonia was established (exceeding maximum allowable concentration for $3 \mathrm{x}$ ), while the other test parameters were in allowable limits,

- Physiological parameters (germination energy and germination), in both cases, have not been proven to be good indicators of water quality, 
- More reliable may be considered some morphological parameters of radish and lettuce (length of root), that reacted by inhibition. Other morphological parameters were not affected by water quality and all values are on the same level of significance, compared to the control.

Bioassay test results indicate the different sensitivity of tested plant species and parameters as well as their validity in assessing water contamination. An expressed variability of parameters indicates their potential as possible bioindicators.

\section{REFERENCES}

[1] Anonimus (1998): Kvalitet voda. Sl. List SRJ, 42/1998.

[2] Bauder, T.A., Waskom, R.M., Sutherland, P.L and Davis, J.G. (2014): Irrigation Water Quality Criteria. Colorado State University, 1-5.

[3] Pravilnik o kvalitetu semena poljoprivrednog bilja.,,Sl. list SFRJ", br. 47/87, 60/87, 55/88 i 81/89 i "Sl. list SRJ", br. 16/92, 8/93, 21/93, 30/94, 43/96, 10/98, 15/2001 i 58/2002.

[4] Uredba o graničnim vrednostima zagađujućih materija u površinskim i podzemnim vodama i sedimentu (Službeni glasnik RS, br. 50/2012).

[5] Uredba o graničnim vrednostima prioritetnih i prioritetnih hazardnih supstanci (Službeni glasnik RS, br. 35/2011). 